University of Nebraska - Lincoln

DigitalCommons@University of Nebraska - Lincoln

\title{
Pearl Millet and Grain Sorghum Yield Response to Water Supply in Nebraska
}

\author{
Nouri Maman \\ University of Nebraska-Lincoln \\ Drew J. Lyon \\ University of Nebraska-Lincoln, drew.lyon@wsu.edu \\ Stephen Mason \\ University of Nebraska-Lincoln, smason1@unl.edu \\ Tom D. Galusha \\ University of Nebraska-Lincoln, tgalusha1@unl.edu \\ Robert Higgins \\ University of Nebraska-Lincoln, rhiggins2@unl.edu
}

Follow this and additional works at: https://digitalcommons.unl.edu/panhandleresext

Part of the Agriculture Commons

Maman, Nouri; Lyon, Drew J.; Mason, Stephen; Galusha, Tom D.; and Higgins, Robert, "Pearl Millet and Grain Sorghum Yield Response to Water Supply in Nebraska" (2003). Panhandle Research and Extension Center. 8.

https://digitalcommons.unl.edu/panhandleresext/8

This Article is brought to you for free and open access by the Agricultural Research Division of IANR at DigitalCommons@University of Nebraska - Lincoln. It has been accepted for inclusion in Panhandle Research and Extension Center by an authorized administrator of DigitalCommons@University of Nebraska - Lincoln. 


\title{
ALTERNATIVE CROPS
}

\section{Pearl Millet and Grain Sorghum Yield Response to Water Supply in Nebraska}

\author{
Nouri Maman, Drew J. Lyon,* Stephen C. Mason, Tom D. Galusha, and Rob Higgins
}

\begin{abstract}
Pearl millet [Pennisetum glaucum (L.) R. Br.] is a drought-tolerant crop that may serve as an alternative summer crop in Nebraska. Field experiments were conducted in 2000 and 2001 near Sidney and Mead, NE, to determine the water use efficiency (WUE) and yield response to water supply at critical developmental stages of pearl millet and grain sorghum [Sorghum bicolor (L.) Moench]. Four water regimes were used: (i) no irrigation, (ii) single irrigation at boot stage, (iii) single irrigation at mid-grain fill, and (iv) multiple irrigations. Pearl millet grain yields were 60 to $80 \%$ that of grain sorghum. Average grain yields at Mead were $5.1 \mathrm{Mg} \mathrm{ha}^{-1}$ for pearl millet and $6.1 \mathrm{Mg}$ $\mathrm{ha}^{-1}$ for grain sorghum. At Sidney, average pearl millet yields were 1.9 and $3.9 \mathrm{Mg} \mathrm{ha}^{-1}$ in 2000 and 2001 , respectively, and average grain sorghum yields were 4.1 and 5.0 $\mathrm{Mg} \mathrm{ha}^{-1}$ in 2000 and 2001, respectively. Both crops used a similar amount of water $(336$ and $330 \mathrm{~mm}$ in 2000 and 370 and $374 \mathrm{~mm}$ in 2001 for pearl millet and grain sorghum, respectively) and responded to irrigation with a linear increase in grain yield as water use increased. Grain sorghum had greater WUE than pearl millet (12.4-13.4 kg vs. 5.1-10.4 kg grain ha ${ }^{-1} \mathrm{~mm}^{-1}$ ). Pearl millet, with lower and less stable yields, does not currently have the potential to be a substitute crop for grain sorghum in Nebraska.
\end{abstract}

$\mathrm{W}$ INTER WHEAT-FALLOW is the prevalent cropping system in the semiarid Central Great Plains, and water is the most limiting resource for dryland crop growth (Smika, 1970). Producers in this region include summer fallow in the rotation to stabilize crop production in a highly variable climate (Lyon et al., 1995). However, precipitation storage efficiency during fallow is least during summer periods when precipitation is greatest (Farahani et al., 1998; Anderson et al., 1999). Therefore, a different approach to water conservation and efficient use of precipitation is needed. The most direct and practical solution to improving efficient use of precipitation may be to include a summer crop in the year following winter wheat that would make better use of summer precipitation (Peterson et al., 1996). Studies have been conducted to investigate more intensive crop management systems involving alternative summer crops in rotation with winter wheat (Anderson et al., 1999; Farahani et al., 1998; Norwood, 1999; Plett et al., 1991). High temperatures and potential evapotranspira-

Dep. of Agron. and Hortic., Univ. of Nebraska, Lincoln, NE 685830915. Paper no. 14019 of the journal series of the Nebraska Agric. Res. Div. Research supported in part by the Anna Elliott Fund, University of Nebraska Foundation, and USAID Grant no. DAN 1254-G-0021 through INTSORMIL, the International Sorghum and Millet Collaborative Research Program. Received 17 March 2003. *Corresponding author (dlyon1@unl.edu).

Published in Agron. J. 95:1618-1624 (2003).

(c) American Society of Agronomy

677 S. Segoe Rd., Madison, WI 53711 USA tion (ET) limit the number of crops grown in this region. Corn (Zea mays L.), sunflower (Helianthus annuus L.), soybean [Glycine $\max (\mathrm{L}$.$) Merr.], and proso millet$ (Panicum miliaceum L.) are possible crops for inclusion in more intensive cropping systems. Grain sorghum was found to be more suitable than corn, soybean, or sunflower due to greater and more consistent yields.

Pearl millet, with its short growth cycle and drought tolerance, may be a better alternative crop than grain sorghum for western Nebraska and a possible diversification crop in eastern Nebraska cropping systems. Plett et al. (1991) indicated that pearl millet did not perform well compared with grain sorghum and corn when grown in western Nebraska. However, those hybrids were experimental, and cool night temperatures resulted in problems with seed set. Progress has been made in pearl millet breeding, and hybrids less sensitive to cold night temperatures have been developed. Pearl millet is usually grown as a rainfed crop on sandy soil in the semiarid tropics of the world, and it can produce yield in waterstressed environments where grain sorghum fails (BOSTID, 1996).

Evapotranspiration, the water removed from soils by evaporation and plant transpiration, is directly related to yield in most cereals. Reduction in yield may occur when irrigation and rainfall combined are insufficient to meet ET demand. Smaller plants transpire less water than larger ones because ET increases with increases in leaf surface area (Cothren et al., 2000). Timing of water supply generally has a larger effect on grain yield than total water for many crops (Shaw, 1988). Both pearl millet and grain sorghum productivity are most sensitive to water stress during flowering and grain filling (Garrity et al., 1983; Hattendorf et al., 1988). Studies on irrigated pearl millet are limited and focused on a single irrigation without consideration of soil water content before irrigation (Chaudhuri and Kanemasu, 1985). We hypothesized that pearl millet would yield better under water stress or shorter growing season conditions than grain sorghum and that the two crops may differ in their response to a range of environmental conditions. The range of environmental conditions included years, locations, and water regimes. The latter is the most limiting factor in rainfed crop production. The objectives of this study were to (i) evaluate pearl millet as a possible alternative crop in Nebraska and (ii) determine the WUE and yield response to water supply for pearl millet and grain sorghum.

Abbreviations: ET, evapotranspiration; $\mathrm{ET}_{\mathrm{p}}$, potential evapotranspiration; WUE, water use efficiency. 


\section{MATERIALS AND METHODS}

Field experiments were conducted in western and eastern Nebraska in 2000 and 2001. The western Nebraska experiment was conducted at the University of Nebraska High Plains Agricultural Laboratory located $8 \mathrm{~km}$ north of Sidney, NE $\left(41^{\circ} 12^{\prime} \mathrm{N}, 103^{\circ} 0^{\prime} \mathrm{W}\right.$ at $1317 \mathrm{~m}$ elevation). Long term (30-yr average) mean growing season (May to September) precipitation is $285 \mathrm{~mm}$, and average last spring freeze and first autumn freeze dates are 14 May and 21 September. Soil at the site is a Keith silt loam (fine-silty, mixed mesic Aridic Argiustoll), and its chemical properties are presented in Table 1 . Available water holding capacities for the soil are 0.51 to $0.58 \mathrm{~cm} \mathrm{~cm}^{-1}$ for the 0 - to $25-\mathrm{cm}$ soil depth, 0.46 to 0.56 for the 25 - to $58-\mathrm{cm}$ soil depth, and 0.51 to 0.56 for the 58 - to $152-\mathrm{cm}$ soil depth (USDA-NRCS and Univ. of Nebraska-Lincoln, 1997).

The eastern Nebraska experiment was conducted at the University of Nebraska Agronomy Farm near Mead, NE $\left(41^{\circ} 8^{\prime} 24^{\prime \prime} \mathrm{N}, 96^{\circ} 17^{\prime} 24^{\prime \prime} \mathrm{W}\right.$ at 369 m elevation). Mean growing season precipitation is $480 \mathrm{~mm}$. Soil at the site is a Sharpsburg silty clay loam (fine, smectitic, mesic, Typic Argiudoll), and its chemical properties are presented in Table 1 . Available water holding capacities for the soil are 0.53 to $0.58 \mathrm{~cm} \mathrm{~cm}^{-1}$ for the 0 - to $36-\mathrm{cm}$ soil depth and 0.46 to $0.51 \mathrm{~cm} \mathrm{~cm}^{-1}$ for the 36- to 114-cm soil depth (USDA-NRCS and Univ. of Nebraska-Lincoln, 1995).

The treatment structure was a $4 \times 2$ factorial in the western and eastern Nebraska experiments, which were dramatically different production environments. Factor 1 consisted of four water regimes to reflect range of environments possible at both locations: (i) no irrigation, (ii) single irrigation at boot stage, (iii) a single irrigation at mid-grain fill, and (iv) multiple irrigation throughout the season. Factor 2 consisted of two crops: a pearl millet hybrid ' $68 \mathrm{~A} \times 086 \mathrm{R}$ ', one of the last pearl millet hybrids released by the breeding program at the University of Nebraska Lincoln, and a grain sorghum hybrid, 'DK 28E', with a short maturity cycle similar to pearl millet. The experimental designs for the two sites were different due to difference in irrigation systems. At Sidney, the irrigation system was a self-propelled, lateral-move system with individually controlled drop nozzles, which allowed the experiment to be conducted as a randomized complete block design with four replications. Plot size was $9.12 \mathrm{~m}$ (12 rows) wide and $14.2 \mathrm{~m}$ long with 3-m alleys between plots. At Mead, a furrow irrigation system was used, and the experiment was conducted as a randomized complete block design with a split-plot treatment arrangement and four replications. The whole-plot treatments were the four water regimes, and the split-plot treatment was crop. Plot size was $6.8 \mathrm{~m}$ wide (nine rows, $76 \mathrm{~cm}$ apart) and $9.1 \mathrm{~m}$ long.

At Sidney, both pearl millet and grain sorghum were notill-planted into wheat stubble using a $76-\mathrm{cm}$ row spacing. Crops were planted on 8 June 2000 and on 11 June 2001. Pearl millet plots were thinned $3 \mathrm{wk}$ after planting. Final plant stands were $111700 \pm 6890$ plants ha $^{-1}$ for pearl millet and $112500 \pm$ 6890 plants ha ${ }^{-1}$ for grain sorghum in 2000 and $135200 \pm$ 10880 plants ha ${ }^{-1}$ for pearl millet and $126800 \pm 10880$ plants $\mathrm{ha}^{-1}$ for grain sorghum in 2001. Soil test results indicated that $\mathrm{N}$ application was not needed in either year. However, $45 \mathrm{~kg}$ $\mathrm{N}$ ha ${ }^{-1}$ was hand- broadcasted as urea (46-0-0) to all plots before planting in 2000 . Weeds were controlled with propazine [6-chloro- $N, N$-bis(1-methylethyl)-1,3,5-triazine-2,4-diamine] applied pre-emergence at $1.12 \mathrm{~kg} \mathrm{ha}^{-1}$ and by hand hoeing.

At Mead, the experimental area was fall chisel-plowed, field cultivated, and roller packed before planting to prepare a seedbed. Pearl millet and grain sorghum were planted in 76- $\mathrm{cm}$ rows on 1 June 2000 and 18 June 2001 at $215000 \pm 10500$
Table 1. Soil chemical properties of the experimental sites.

\begin{tabular}{|c|c|c|c|c|c|}
\hline \multicolumn{3}{|c|}{ Sidney } & \multicolumn{3}{|c|}{ Mead } \\
\hline Soil depth & 2000 & 2001 & Soil depth & 2000 & 2001 \\
\hline cm & \multicolumn{2}{|c|}{$\mathbf{m g ~ k g}^{-1} \mathbf{N O}_{3}-\mathbf{N}$} & cm & \multicolumn{2}{|c|}{$-\mathrm{mg} \mathrm{kg}^{-1} \mathrm{NO}_{3}-\mathrm{N}$} \\
\hline $\begin{array}{l}0-30 \\
30-61 \\
61-122\end{array}$ & $\begin{array}{l}5.6 \\
11.2 \\
26.1\end{array}$ & $\begin{array}{l}3.4 \\
3.3 \\
14.4\end{array}$ & $\begin{array}{c}0-15 \\
15-61 \\
61-91 \\
91-122\end{array}$ & $\begin{array}{l}5.1 \\
2.9 \\
1.7 \\
2.0\end{array}$ & $\begin{array}{l}\mathbf{7 . 7} \\
\mathbf{4 . 4} \\
\mathbf{3 . 5} \\
\mathbf{3 . 0}\end{array}$ \\
\hline \multicolumn{6}{|c|}{ Soil surface to $20 \mathrm{~cm}$} \\
\hline pH & 7.2 & 6.8 & & 5.7 & 6.3 \\
\hline $\begin{array}{c}\text { Soil organic C, } \\
\text { mg kg }^{-1}\end{array}$ & 21 & 20 & & 30 & 30 \\
\hline$P, \mathbf{m g ~ k g}{ }^{-1}$ & 173 & 54 & & 30 & 43 \\
\hline $\mathrm{K}, \mathrm{cmol} \mathrm{kg}^{-1}$ & 2.6 & 2.6 & & 1.2 & 1.2 \\
\hline
\end{tabular}

seeds $\mathrm{ha}^{-1}$. These seeding rates resulted in plant population of $175600 \pm 2250$ plants ha $^{-1}$ for grain sorghum and $174000 \pm$ 8700 plants ha $^{-1}$ for pearl millet. Fertilizer was broadcastapplied and incorporated before planting at the rates of 112 $\mathrm{kg} \mathrm{N} \mathrm{ha}^{-1}$ in both years and $21.4 \mathrm{~kg} \mathrm{P} \mathrm{ha}^{-1}$ in 2000 . Weeds were controlled with herbicide application, cultivation, and hand hoeing. Herbicides included atrazine [6-chloro- $N$-ethyl$N^{\prime}$-(1-methyl)-1,3,5-triazine-2,4-diamine] applied pre-emergent at $1.2 \mathrm{~kg} \mathrm{ha}^{-1}$ followed by $0.6 \mathrm{~kg} \mathrm{ha}^{-1}$ metolachlor [2-chloro-(2-ethyl-6-methylphenyl)- $N$-(2-methoxy-1-methylethyl)acetamide] and $0.6 \mathrm{~kg} \mathrm{ha}^{-1}$ bentazon [3-(1-methylethyl)(1H)-2,1,3-benzothiadiazin-4(3H)-one 2,2-dioxide] applied when pearl millet reached the three-leaf stage. The insecticide tefluthrin $\{(2,3,5,6$-tetrafluoro-4-methylphenyl $)$ methyl $[1 \alpha, 3 \alpha$ (Z)-(+)-]-3-(2-chloro-3,3,3-trifluoro-1-propenyl)-2,2-dimethylcyclopropanecarboxylate\} was applied at $0.5 \mathrm{~kg} \mathrm{ha}^{-1}$ to control green bug (Schizaphis graminum Rondani) infestation in 2001.

At Mead, the decision to irrigate in all irrigation treatments was based on physical observation of crop stress and soil water content using the feel method (USDA-NRCS, 1998). Furrow irrigation was used, with flow rate being controlled by adjusting the irrigation pump speed and openings. At the beginning of each irrigation, water was applied at the greatest rate $\left(1200 \pm 20 \mathrm{~L} \mathrm{~min}^{-1}\right)$ that could be used without causing excessive erosion of the furrow, followed by slower application. Multiple-irrigation plots were irrigated on 25 July, 14 Aug., 16 Aug., and 30 Aug. in 2000 and on 26 July, 3 Aug., and 22 Aug. in 2001. Main plots were irrigated on 25 July 2000 and 3 Aug. 2001 for boot irrigation treatments and on 16 Aug. 2000 and 22 Aug. 2001 for mid-grain fill irrigation treatments. Each irrigation brought the soil profile to field capacity.

At Sidney, two 1.52-m-long aluminum access tubes were installed in the central area of each plot. A neutron probe (Campbell Pacific 503 DR, Campbell Pacific, Pacheco, CA) was used to monitor soil moisture weekly in $30-\mathrm{cm}$ increments during the growing season and immediately after harvest. Soil water content in the surface $30 \mathrm{~cm}$ was measured gravimetrically. In all irrigated treatments, water was applied to bring the soil water level to $80 \%$ of the available soil water capacity (318 $\mathrm{mm}$ for $152 \mathrm{~cm}$ soil profile). Water was applied whenever available soil water fell below $70 \%$ of available soil water capacity in the multiple-irrigation treatment. Soil available water capacity was defined as the difference between the amount of soil water at field capacity and the amount at the wilting point and was $318 \mathrm{~mm}$ for the surface $1.5 \mathrm{~m}$ of soil. Water applications were made in $25-\mathrm{mm}$ increments. Water applications were made with a 1-d interval between applications to avoid runoff. The entire experiment was irrigated with $25 \mathrm{~mm}$ of water after planting to promote germination in 2000. The initial water measurement was made after this application. A total of $305 \mathrm{~mm}$ of water was applied in the multiple- 
Table 2. Growing season monthly average temperatures and total precipitation and evapotranspiration at Sidney, NE. Source: High Plains Regional Climate Center, University of Nebraska, Lincoln.

\begin{tabular}{|c|c|c|c|c|c|c|c|c|c|c|c|c|}
\hline \multirow[b]{3}{*}{ Month } & \multicolumn{6}{|c|}{ Temperature } & & & & & & \\
\hline & \multicolumn{2}{|c|}{2000} & \multicolumn{2}{|c|}{2001} & \multicolumn{2}{|c|}{ 30-yr avg. } & \multicolumn{3}{|c|}{ Precipitation } & \multicolumn{3}{|c|}{ Potential evapotranspiration } \\
\hline & Low & High & Low & High & Low & High & 2000 & 2001 & 30-yr avg. & 2000 & 2001 & 30-yr avg. \\
\hline & & & & & & & & & & & & \\
\hline May & 7.0 & 22.7 & 6.1 & 19.8 & 5.6 & 21.4 & 45 & 100 & 77 & 236 & 193 & 196 \\
\hline June & 10.7 & 28.9 & 10.5 & 27.5 & 11.2 & 27.4 & 27 & 36 & 73 & 300 & 243 & 230 \\
\hline July & 15.3 & 33.1 & 16.2 & 32.3 & 14.4 & 31.3 & 18 & 92 & 62 & 289 & 255 & 275 \\
\hline August & 14.8 & 33.1 & 13.6 & 31.4 & 12.9 & 29.9 & 12 & 61 & 39 & 292 & 257 & 243 \\
\hline September & 8.2 & 25.9 & 9.4 & 25.7 & 7.2 & 24.6 & 39 & 65 & 34 & 229 & 191 & 187 \\
\hline Total & & & & & & & 141 & 354 & 285 & 1347 & 1114 & 1131 \\
\hline
\end{tabular}

irrigation treatment in 2000 and $102 \mathrm{~mm}$ was applied in 2001. The total amount of supplied water for the boot stage irrigation treatment was $127 \mathrm{~mm}$ in 2000 and $25 \mathrm{~mm}$ in 2001. The total amount of water applied for the grain fill irrigation treatment was $127 \mathrm{~mm}$ in 2000 and $76 \mathrm{~mm}$ in 2001.

Evapotranspiration, considered to be water used (WU), was estimated using WU $=\mathrm{SWP}+\mathrm{GSP}+\mathrm{AW}-\mathrm{SWH}-$ $R$, where SWP is soil water at planting, GSP is growing season precipitation, AW is applied water, SWH is soil water at harvest, and $R$ is deep percolation and runoff. Observations suggested that deep percolation and runoff were negligible in this study. Water use efficiency was calculated on a grain yield and biomass basis by dividing grain yield by water used and the total aboveground biomass by water used.

A time-scaled fraction of growing season defined as the thermal (or growing degree) units accumulated from planting to each of these growth stages was used. Thermal units were calculated as the mean daily air temperature (maximum plus minimum divided by 2$)$ minus a base temperature $\left(10^{\circ} \mathrm{C}\right.$ for both pearl millet and grain sorghum; Ong, 1983). Any daily value of thermal units that was negative was considered to be $0^{\circ} \mathrm{C}$ when accumulating thermal units for the season.

Two central rows, $3 \mathrm{~m}$ long, were hand-harvested from each plot for panicles and stover weight, grain yield, total aboveground biomass, and harvest index determination at both sites. Panicles were weighed and threshed separately, and grain yields were corrected to $140 \mathrm{~g} \mathrm{~kg}^{-1}$ water content. Total aboveground biomass was calculated by summing nonthreshed panicle weights and stover weights.

Data from Sidney and Mead were analyzed separately due to difference in irrigation methods and experimental design. Within each location, analysis of variance to determine the significance level of interactions between treatments and their main effect was done with the mixed model procedure of SAS as presented by Littell et al. (1996) for individual years or pooled across years when Hartley's test for homogeneity of variances (Dowdy and Wearden, 1991) allowed it. Single degree-of-freedom contrasts were performed using SAS procedures. Linear regression analysis was used to determine the response of grain yield and total aboveground biomass to seasonal water use.

\section{RESULTS AND DISCUSSION}

The 30-yr average growing season rainfall at Mead is $68 \%$ greater than at Sidney (Tables 2 and 3). During the $2 \mathrm{yr}$ of this experiment, high and low temperatures were near long-term averages at Mead and slightly greater than average at Sidney (Tables 2 and 3). Rainfall was $50 \%$ less than the long-term seasonal average at Sidney and $25 \%$ less at Mead in 2000. Rainfall was above the long-term average for both locations in 2001. However, Sidney rainfall was $24 \%$ above the long-term average and evenly distributed throughout the season while above-average rainfall was received only in May at Mead. The 30-yr average growing season potential evapotranspiration $\left(\mathrm{ET}_{\mathrm{p}}\right.$ ) at Sidney is $40 \%$ greater than at Mead, and the $\mathrm{ET}_{\mathrm{p}} /$ precipitation ratio, an indicator of water-stressed environment, is 4.0 for Sidney and 1.7 for Mead (Tables 2 and 3). This ratio was 9.6 in 2000 and 3.2 in 2001 at Sidney while it was 2.6 in 2000 and 2.1 in 2001 at Mead.

Differences between pearl millet and grain sorghum phenology were more pronounced in 2000 than in 2001. Both crops reached boot and mid-grain fill stages earlier in 2001 than in 2000. Pearl millet reached boot, midgrain fill, and physiological maturity earlier than grain sorghum at Mead. At Sidney, water regime affected crop phenology in 2000 but not in 2001. Pearl millet in the multiple-irrigation treatment reached boot stage at 633 growing degree days while in the other water treatments, the boot stage was reached at 706 growing degree days (data not presented).

Table 3. Growing season monthly average temperatures and total precipitation and evapotranspiration at the Agronomy Farm near Mead, NE. Source: High Plains Regional Climate Center, University of Nebraska, Lincoln.

\begin{tabular}{|c|c|c|c|c|c|c|c|c|c|c|c|c|}
\hline \multirow[b]{3}{*}{ Month } & \multicolumn{6}{|c|}{ Temperature } & & & & & & \\
\hline & \multicolumn{2}{|c|}{2000} & \multicolumn{2}{|c|}{2001} & \multicolumn{2}{|c|}{ 30-yr avg. } & \multicolumn{3}{|c|}{ Precipitation } & \multicolumn{3}{|c|}{ Potential evapotranspiration } \\
\hline & Low & High & Low & High & Low & High & 2000 & 2001 & 30-yr avg. & 2000 & 2001 & 30-yr avg. \\
\hline & & & & & & - & & & + & & & \\
\hline May & 11.2 & 26.3 & 11.5 & 23.4 & 10.6 & 23.4 & 70 & 230 & 105 & 207 & 196 & 167 \\
\hline June & 14.4 & 28.5 & 15.5 & 28.0 & 16.2 & 29.1 & 152 & 40 & 106 & 215 & 218 & 189 \\
\hline July & 14.4 & 29.3 & 19.8 & 31.9 & 19.2 & 31.7 & 88 & 25 & 87 & 163 & 191 & 185 \\
\hline August & 19.0 & 31.1 & 17.1 & 30.9 & 17.7 & 30.1 & 43 & 79 & 92 & 166 & 194 & 145 \\
\hline September & 11.1 & 28.0 & 11.2 & 25.0 & 12.3 & 25.0 & 15 & 67 & 90 & 210 & 130 & 119 \\
\hline Total & & & & & & & 369 & 440 & 480 & 960 & 929 & 805 \\
\hline
\end{tabular}




\section{Grain and Biomass Yields}

Grain and aboveground biomass yields for pearl millet and grain sorghum were greater at Mead than at Sidney (Table 4). Crop and water treatments did not interact for grain or aboveground biomass yields at either location. Pearl millet yielded less than grain sorghum in both years and locations. The grain yield difference between the two crops was greatest in 2000 at Sidney where pearl millet yield averaged $46 \%$ of the average grain sorghum yield. Pearl millet aboveground biomass was also less than that of grain sorghum at Sidney in 2000. Andrews et al. (1998) reported that when grown in sorghum production environments in the Great Plains without irrigation, pearl millet yields were 80 to $85 \%$ of grain sorghum hybrids of comparable maturity, averaging 2 to $3 \mathrm{Mg} \mathrm{ha}^{-1}$ in regional tests. In 2001 at Sidney, and 2000 and 2001 at Mead, overall pearl millet grain yields were 78,84 , and $82 \%$ of grain sorghum yields, respectively (Table 4 ).

Irrigation increased grain yield at both locations in both years (Table 4), but biomass production was increased by irrigation only at Sidney in 2000. Single irrigation at boot and mid-grain fill stages resulted in less grain and aboveground biomass yields compared with the multiple-irrigations treatment at Sidney. Even though these are the most sensitive stages to water stress, both crops responded to irrigation at all growth stages. At Mead, grain yield with a single irrigation was similar to that obtained with the multiple-irrigation treatment in 2000. In 2001, with less June and July precipitation, supplemental water at boot and mid-grain fill stages was inadequate to produce grain yield equal to the multiple-irrigations treatment. Grain yield was greater with a single irrigation at mid-grain fill than at boot stage at Sidney while at Mead in 2000, greater grain yield was produced with irrigation at the boot stage. No grain yield difference between boot and midgrain fill water applications was present at Mead in 2001. The two single irrigation treatments produced the same amount of aboveground biomass in both locations during the $2 \mathrm{yr}$ of study.
Hartley's test for homogeneity of variances (Dowdy and Wearden, 1991) indicated that across-years analysis was appropriate for Mead data but not Sidney. Water regime and crop $\times$ year interaction effects were present for grain and biomass yield at Mead. In the no-irrigation treatment at Mead, pearl millet grain yield was about $91 \%$ of grain sorghum yield, which is greater than the 80 to $85 \%$ reported by Andrews et al. (1998) and Christensen et al. (1987). Compared with the no-irrigation treatment, irrigation increased grain yield, but not aboveground biomass, of both crops. However, the increase in pearl millet grain yields was less than that of grain sorghum. A single irrigation at the boot stage increased pearl millet grain yield by $2 \%$ and grain sorghum yield by $13 \%$ compared with no irrigation. With this treatment, pearl millet grain yield was about $82 \%$ that of grain sorghum. When water was applied at midgrain fill, pearl millet and grain sorghum produced 10 and $19 \%$ more grain than with no irrigation. In the multiple-irrigations treatment, pearl millet produced $8 \%$ more than with no irrigation. Grain sorghum in the multiple-irrigation treatment produced $6.7 \mathrm{Mg} \mathrm{ha}^{-1}$, an increase of $26 \%$ compared with the no-irrigation treatment. In the multiple-irrigation treatment, pearl millet grain yield was $78 \%$ of grain sorghum yield.

Pearl millet was less responsive than grain sorghum to irrigation. Pearl millet had lower grain yield than grain sorghum in all of the wide range of production environments resulting from the $2 \mathrm{yr}$, two locations, and four water regimes. Our experiments using new hybrids support and extend previous reports that found that grain sorghum is better adapted than pearl millet in eastern Nebraska (Palé et al., 2003) and Kansas (Chaudhuri and Kanemasu, 1985; Christensen et al., 1987). This included the high-elevation, short growing season, lowrainfall environment in western Nebraska and a wide range of production environments resulting from imposing different water regimes at both locations.

\section{Water Use and Water Use Efficiency}

Pearl millet and grain sorghum under the different irrigation treatments did not differ in water use; crop $\times$

Table 4. Mean pearl millet and grain sorghum grain yield and aboveground biomass, as affected by water regime at Sidney and Mead, NE.

\begin{tabular}{|c|c|c|c|c|c|c|c|c|}
\hline \multirow[b]{3}{*}{ Treatments } & \multicolumn{4}{|c|}{ Sidney } & \multicolumn{4}{|c|}{ Mead } \\
\hline & \multicolumn{2}{|c|}{2000} & \multicolumn{2}{|c|}{2001} & \multicolumn{2}{|c|}{2000} & \multicolumn{2}{|c|}{2001} \\
\hline & Grain & Biomass & Grain & Biomass & Grain & Biomass & Grain & Biomass \\
\hline & & & & $-\mathbf{N}$ & 1 & & & \\
\hline \multicolumn{9}{|l|}{ Crop } \\
\hline Pearl millet & 1.9 & 8.0 & 3.9 & 14.6 & 4.8 & 13.1 & 5.3 & 16.7 \\
\hline Sorghum & 4.1 & 9.1 & 5.0 & 14.6 & 5.7 & 12.8 & 6.5 & 15.5 \\
\hline \multicolumn{9}{|l|}{ Water regime } \\
\hline No irrigation & 1.4 & 5.5 & 3.6 & 14.3 & 4.9 & 12.3 & 5.2 & 15.7 \\
\hline Multiple irrigation & 4.9 & 13.4 & 5.5 & 14.0 & 5.5 & 13.8 & 6.5 & 16.5 \\
\hline Boot irrigation & 2.7 & 8.5 & 4.1 & 15.8 & 5.6 & 12.7 & 5.8 & 16.2 \\
\hline Mid-grain fill irrigation & 3.0 & 8.6 & 4.6 & 14.2 & 5.1 & 13.1 & 6.0 & 16.1 \\
\hline \multicolumn{9}{|l|}{$F$ test and contrast probabilities } \\
\hline Crop (C) & $<0.01$ & $<\mathbf{0 . 0 1}$ & $<0.01$ & 0.99 & $<0.01$ & 0.45 & $<0.01$ & $<0.01$ \\
\hline Water regime (WR) & $<0.01$ & $<\mathbf{0 . 0 1}$ & $<0.01$ & 0.02 & 0.01 & 0.11 & $<0.01$ & 0.38 \\
\hline $\mathbf{C} \times \mathbf{W R}$ & 0.14 & 0.12 & 0.62 & 0.21 & 0.12 & 0.90 & 0.08 & 0.21 \\
\hline \multicolumn{9}{|l|}{ Contrasts } \\
\hline Nonirrigated vs. irrigated & $<0.01$ & $<\mathbf{0 . 0 1}$ & $<0.01$ & 0.45 & $<0.01$ & 0.09 & $<0.01$ & 0.17 \\
\hline Multiple vs. partial irrigation & $<0.01$ & $<\mathbf{0 . 0 1}$ & $<0.01$ & $<0.01$ & 0.32 & 0.08 & 0.01 & 0.30 \\
\hline Boot vs. mid-grain fill irrigation & 0.39 & 0.98 & $<0.01$ & 0.73 & 0.02 & 0.49 & 0.47 & 0.82 \\
\hline
\end{tabular}


Table 5. Mean pearl millet and grain sorghum water use and water use efficiency as affected by water regime at Sidney, NE.

\begin{tabular}{|c|c|c|c|c|c|c|}
\hline & \multicolumn{3}{|c|}{2000} & \multicolumn{3}{|c|}{2001} \\
\hline & \multirow[b]{2}{*}{ Water use } & \multicolumn{2}{|c|}{ Water use efficiency } & \multirow[b]{2}{*}{ Water use } & \multicolumn{2}{|c|}{ Water use efficiency } \\
\hline & & Grain & Biomass & & Grain & Biomass \\
\hline & mm & $-\mathbf{k}$ & $\mathrm{a}^{-1}$ & mm & $-\mathbf{k}$ & $n^{-1}$ \\
\hline \multicolumn{7}{|l|}{ Crop } \\
\hline Pearl millet & 336 & 5.1 & 24.1 & 370 & 10.4 & 39.6 \\
\hline Grain sorghum & 339 & 11.8 & 28.5 & 374 & 13.4 & 39.3 \\
\hline \multicolumn{7}{|l|}{ Water regime } \\
\hline No irrigation & 227 & 6.2 & 24.3 & 327 & 10.9 & 43.6 \\
\hline Multiple irrigation & 476 & 10.2 & 28.0 & 444 & 12.5 & 35.6 \\
\hline Boot irrigation & 326 & 8.1 & 26.1 & 357 & 11.4 & 39.1 \\
\hline Mid-grain fill irrigation & 319 & 9.4 & 26.8 & 360 & 12.9 & 39.4 \\
\hline \multicolumn{7}{|l|}{$F$ test and contrast probabilities } \\
\hline Crop (C) & 0.34 & $<0.01$ & 0.03 & 0.37 & $<0.01$ & 0.77 \\
\hline Water regime (WR) & $<0.01$ & 0.16 & 0.57 & $<\mathbf{0 . 0 1}$ & $<0.01$ & $<\mathbf{0 . 0 1}$ \\
\hline $\mathbf{C} \times \mathbf{W R}$ & $<0.01$ & 0.19 & 0.45 & 0.50 & 0.72 & 0.58 \\
\hline \multicolumn{7}{|l|}{ Contrasts } \\
\hline Nonirrigated vs. irrigated & $<0.01$ & $<0.01$ & 0.23 & $<0.01$ & $<0.01$ & $<0.01$ \\
\hline Multiple vs. partial irrigation & $<0.01$ & 0.16 & 0.52 & $<0.01$ & 0.30 & 0.01 \\
\hline Boot vs. mid-grain fill irrigation & 0.19 & 0.26 & 0.81 & 0.70 & $<0.01$ & 0.83 \\
\hline
\end{tabular}

irrigation treatment interaction effects on water use occurred in 2000 but not 2001 at Sidney (Table 5). The interaction in 2000 was due to grain sorghum using $18 \mathrm{~mm}$ more water with a single irrigation at boot stage than with a single irrigation at mid-grain fill while water use was similar for pearl millet for the same irrigation treatments. More water was used by pearl millet and grain sorghum in 2001 than in 2000 due to greater soil water availability at planting and greater rainfall during the growing season in 2001 (Table 2). The amounts of water used by the two crops were similar to those reported by Hattendorf et al. (1988) and less than reported by Chaudhuri and Kanemasu (1985) for well-watered conditions. In our experiment, the two crops did not differ in the amount of water used during the two growing seasons even though grain sorghum produced more grain yield in both years and greater biomass in 2000 . The two crops did not differ in soil water depletion; the soil water content at planting $(201 \pm 3 \mathrm{~mm}$ in 2000 and $239 \pm 2 \mathrm{~mm}$ in 2001 for pearl millet and $204 \pm 3 \mathrm{~mm}$ in 2000 and $238 \pm 2 \mathrm{~mm}$ in 2001 for grain sorghum) and after harvest $(123 \pm 2 \mathrm{~mm}$ in 2000 and $168 \pm 3 \mathrm{~mm}$ in 2001 for pearl millet, $122 \pm 2 \mathrm{~mm}$ in 2000 , and $163 \pm$ $3 \mathrm{~mm}$ in 2001 for grain sorghum) were similar in both years.

Water use at Sidney was influenced by irrigation in both years. Differences in water use among water treatments were greater in 2000 than in 2001. The amount of water used by the crops in the no-irrigation and singleirrigation treatments was always less than with the multiple-irrigation treatment (Table 5). These results indicate that even with the good rainfall conditions of 2001, water requirement of the two crops was not fulfilled in the no-irrigation or single-irrigation treatments. Even though the two crops are drought tolerant, they are able to use additional water to increase yield. More water was used when supplemental water was applied at mid-grain fill than when applied at boot stage, but this difference was not significant in 2001. These results indicate that the crops' water demand was likely greater during this period because of greater water demand for kernel growth.
In both years, pearl millet and grain sorghum grain yield increased linearly with increased water use at Sidney (Fig. 1). Both pearl millet and grain sorghum used water more efficiently in 2001 than in 2000 for the production of grain and biomass (Table 4). Pearl millet used the same amount of water as grain sorghum but produced less grain yield. Therefore, pearl millet had lower WUE than grain sorghum, except for biomass WUE in 2001. Pearl millet grain WUE was only $41 \%$ that of grain sorghum, but biomass WUE for pearl millet was $81 \%$ as efficient as that for grain sorghum in 2000 . Water use efficiency was greater for both crops in 2001. Pearl millet and grain sorghum had the same biomass WUE, but pearl millet grain WUE was $78 \%$ that of grain sorghum in 2001. It was expected that pearl millet would have similar or better grain yield than grain sorghum in 2000. Pearl millet was able to improve its yield and WUE with improved conditions. Christensen et al. (1987) found that in unfavorable environments, pearl millet had better yield, and its response to changing environment was similar to that of grain sorghum. Grain sorghum had a more stable and consistent response to water use and production than pearl millet in this study.

Water use efficiencies were influenced by water regime treatments only in 2001. In 2000, crops in the noirrigation treatment had similar biomass WUE but lower grain WUE than when supplemental water was applied (Table 5). Crops in the no-irrigation treatment had lower grain WUE, and greater biomass WUE in 2001, indicating that supplemental water helped increase the proportion of grain relative to total biomass (i.e., the harvest index).

Pearl millet had a greater change in biomass WUE to grain WUE ratio than grain sorghum, with a change from 4.7 in 2000 to 3.8 in 2001, while for grain sorghum, this ratio changed from 2.4 in 2000 to 2.9 in 2001. These results are similar to what was reported by Chaudhuri and Kanemasu (1985). Pearl millet was less efficient than grain sorghum in partitioning photoassimilates to grain.

Harvest index is a parameter for interpreting agro- 


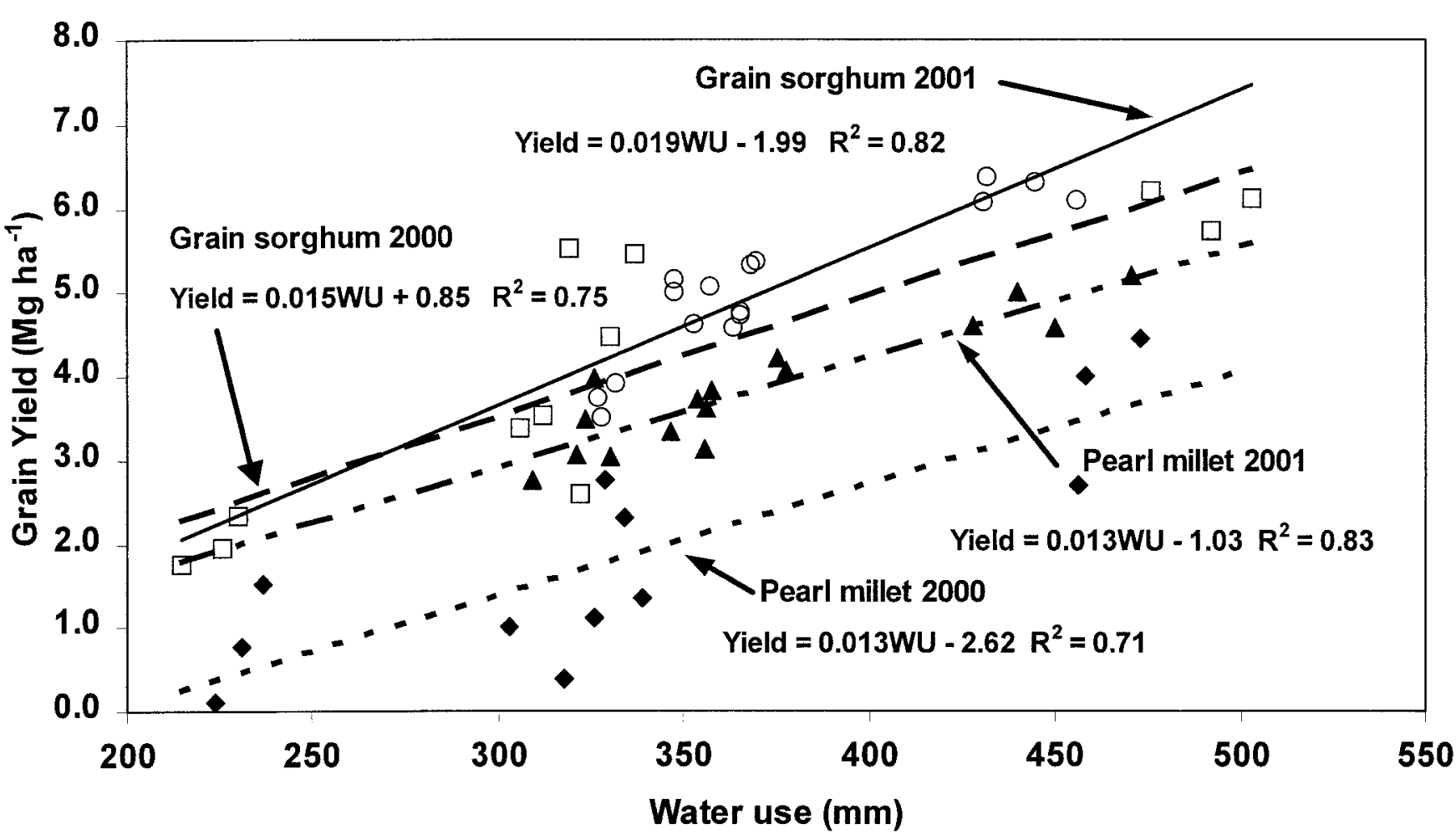

Pearl millet 2000

Grain sorghum 2000

A Pearl millet 2001

O Grain sorghum 2001

Fig. 1. Grain yield response of pearl millet and grain sorghum to water use at Sidney, NE. Each data point represents plot grain yield. WU, water use.

nomic data with stress effect differences. Prihar and Stewart (1991) suggested that harvest index can be applied as a reference for interpreting useful parameters for comparing crop species or cultivars for their capability to partition photoassimilates to grain within a given environment. Hay and Walker (1989) observed that grain growth can be unresponsive to increased assimilate supply resulting in sink limitation even though its final weight does not reach the potential of the cultivar. The lower harvest index for pearl millet may not be due to source limitation, but rather to the high tillering capacity of pearl millet. New tillers compete with grain fill for photoassimilates, particularly when they are under limited water conditions. In this case, the tillering capacity becomes a disadvantage for pearl millet grain production. Another reason may be pearl millet grain set was limited by low temperature during flowering, as suggested by Christensen et al. (1987). However, during the flowering period in August, temperatures were greater in 2000 compared with 2001, but grain yields were much greater in 2001, indicating that low temperatures were not the reason for the reduced yields in 2000 . During the pollination period, greater $\mathrm{ET}_{\mathrm{p}}$ was the most probable reason for low yield in 2000.

\section{CONCLUSION}

Pearl millet and grain sorghum yields were greater in eastern than in western Nebraska due to better environmental growing conditions, greater rainfall, and higher night temperature. In both environments, pearl millet grain yields were 60 to $80 \%$ that of grain sorghum. At Sidney, pearl millet grain yields were much greater in 2001 than in 2000 despite lower night temperature during the pollination period. This indicated that environmental factors other than low temperature were likely the reason for pearl millet's low yield in 2000. Pearl millet and grain sorghum responded to irrigation with a linear increase in grain yield as water use increased. Irrigated environments produced greater grain yield for both crops, especially grain sorghum in 2001. Single irrigation increased grain yield but was not enough to reach the yield obtained with multiple irrigation. With greater grain yield, grain sorghum had greater WUE on a grain basis. A single irrigation at mid-grain fill led to similar WUE as multiple irrigations.

Pearl millet may have lower yield potential across the wide range of environments as a result of limited plant breeding research. Pearl millet production was also less stable and more affected by unfavorable environmental conditions than grain sorghum production, primarily due to instability in harvest index. Pearl millet does not have the potential to be a substitute feed-grain crop for grain sorghum in Nebraska at this time. In addition to market development needs, additional plant breeding efforts are needed to develop greater-yielding hybrids before pearl millet will become a viable crop alternative in Nebraska. 


\section{REFERENCES}

Anderson, R.L., R.A. Bowman, D.C. Nielsen, M.F. Vigil, R.M. Aiken, and J.G. Benjamin. 1999. Alternative crop rotations for the Central Great Plains. J. Prod. Agric. 12:95-99.

Andrews, D.J., J.F. Rajewski, and S.C. Mason. 1998. Grain pearl millet: A new crop being developed at UNL. Ext. Visions 2(1):2-4.

[BOSTID] Board on Science and Technology for International Development. 1996. Lost crops of Africa. Volume I. National Academic Press, Washington, DC.

Chaudhuri, U.N., and E.T. Kanemasu. 1985. Growth and water use of sorghum and pearl millet. Field Crops Res. 10:113-124.

Christensen, N.B., R.L. Vanderlip, and G.A. Milliken. 1987. Response of pearl millet to grain sorghum environments. Field Crops Res. 16:337-348.

Cothren, J.T., J.E. Matocha, and L.E. Clark. 2000. Integrated crop management for sorghum. p. 409-441. In W.C. Smith and R.A. Frederiksen (ed.) Sorghum: Origin, history, technology, and production. John Wiley \& Sons, New York.

Dowdy, S., and S. Wearden. 1991. Statistics for research. John Wiley \& Sons, New York.

Farahani, H.J., G.A. Peterson, and D.G. Westfall. 1998. Dryland cropping intensification: A fundamental solution to efficient use of precipitation. Adv. Agron. 64:197-223.

Garrity, P.D., C.Y. Sullivan, and D.G. Watts. 1983. Moisture deficits and grain sorghum performance: Drought stress conditioning. Agron. J. 75:997-1004.

Hattendorf, M.J., M.S. Dedelfs, B. Amos, L.R. Stone, and R.E. Given, Jr. 1988. Comparative water use characteristics of six row crops. Agron. J. 80:80-85.

Hay, K.M.R., and A.J. Walker. 1989. An introduction to the physiology of crop yields. Longman Sci. and Tech., New York.
Littell, R.C., G.A. Milliken, W.W. Stroup, and R.D. Wolfinger. 1996. SAS system for mixed models. SAS Inst., Cary, NC.

Lyon, D.J., F. Boa, and T.J. Arkebauer. 1995. Water-yield relations of several spring planted dryland crops following winter wheat. J. Prod. Agric. 8:281-286.

Norwood, C.A. 1999. Water use and yield of dryland row crops as affected by tillage. Agron. J. 91:108-115.

Ong, C.K. 1983. Response to temperature in a stand of pearl millet (Pennisetum typhoides): II. Reproductive development. J. Exp. Bot. 34:337-348.

Palé, S.B., S.C. Mason, and T.D. Galusha. 2003. Planting time for early-season pearl millet and grain sorghum in Nebraska. Agron. J. 95:1047-1053.

Peterson, G.A., A.J. Schlegel, D.L. Tanaka, and O.R. Jones. 1996. Precipitation use efficiency as affected by cropping and tillage systems. J. Prod. Agric. 9:180-186.

Plett, S., L.A. Nelson, and M.D. Clegg. 1991. Alternative crop prospects in Western Nebraska. J. Prod. Agric. 4:162-166.

Prihar, S.S., and B.A. Stewart. 1991. Sorghum HI in relation to plant size, environment, and cultivar. Agron. J. 83:603-608.

Shaw, R.H. 1988. Climatic requirements. p. 609-638. In G.F. Sprague and J.W. Dudley (ed.) Corn and corn improvement. 3rd ed. Agron. Monogr. 18. ASA, CSSA, and SSSA., Madison, WI.

Smika, D.E. 1970. Summer fallow for dryland winter wheat in the semiarid Great Plains. Agron. J. 62:15-17.

USDA-NRCS. 1998. Estimating soil moisture by feel and appearance. Program Aid no. 1619. USDA-NRCS, Washington, DC.

USDA-NRCS and University of Nebraska-Lincoln. 1995. Soil survey of Saunders County. U.S. Gov. Print. Office, Washington, DC.

USDA-NRCS and University of Nebraska-Lincoln. 1997. Soil survey of Cheyenne County. U.S. Gov. Print. Office, Washington, DC. 